\title{
Penerbitan Sertipikat Hak Milik Oleh Kantor Pertanahan yang Berdasarkan Letter $C$ (Studi Kasus pada Sertipikat Hak Milik Nomor 2092/Margosari di Kantor Pertanahan Kabupaten Kulonprogo)
}

\author{
Khanifan \\ Fakultas Hukum Universitas Islam Indonesia Yogyakarta Indonesia \\ Jln. Cik Di Tiro No. 1 Yogyakarta Indonesia \\ jolali1990@gmail.com
}

\begin{abstract}
The research aims to determine the mechanism of issuance and legal certainty of Freehold Certificate No. 2092/Margosari on behalf of Ranu Dikromo which occupies Persil 62a P Class III on behalf of Sonto Permono. This study uses an empirical juridical approach, namely by examining secondary data first then followed by conducting research on primary data in the field. The results of the study conclude, first, the issuance of a certificate of property rights by the Kulon Progo Regency Land Office through stages based on the prevailing laws and regulations in Indonesia, however, many of the legal requirements for registration applications are manipulated and there are indications of illegal acts. Second, legal certainty SHM No. 2092/Margosari can still be contested in terms of its legality. The heirs of Sonto Permono who object to the issuance of the certificate can file a lawsuit at the local court. The court will decide on the basis of evidence that convinces the judge whether there has been an illegal act of issuing the certificate or affirming the issuance of the certificate.
\end{abstract}

Key Words: Issuance of certificate; land office; Letter C

\begin{abstract}
Abstrak
Penelitian memiliki tujuan untuk mengetahui mekanisme penerbitan dan kepastian hukum Sertipikat Hak Milik Nomor 2092/Margosari atas nama Ranu Dikromo yang menempati Persil 62a P Kelas III atas nama Sonto Permono. Penelitian ini menggunakan pendekatan yuridis empiris, yaitu dengan meneliti data sekunder terlebih dahulu kemudian dilanjutkan dengan mengadakan penelitian terhadap data primer di lapangan. Hasil penelitian menyimpulkan, pertama, penerbitan sertipikat hak milik oleh Kantor Pertanahan Kabupaten Kulon Progo melalui tahapan-tahapan yang berdasarkan peraturan perundang-undangan yang berlaku di Indonesia, akan tetapi syarat sahnya permohonan pendaftaran banyak yang dimanipulasi dan terindikasi ada perbuatan melawan hukum. Kedua, kepastian hukum SHM No. 2092/Margosari masih bisa diganggu gugat keabsyahannya. Pihak ahli waris Sonto Permono yang keberatan atas terbitnya sertipikat bisa mengajukan gugatan ke Pengadilan setempat. Pengadilan akan memutuskan berdasarkan alat bukti yang meyakinkan hakim apakah ada perbuatan melawan hukum penerbitan sertipikat atau menguatkan penerbitan sertipikat tersebut.
\end{abstract}

Kata-kata Kunci: Penerbitan sertipikat; kantor pertanahan; Letter C 


\section{Pendahuluan}

Undang-undang Nomor 5 Tahun 1960 tentang Peraturan Dasar Pokokpokok Agraria atau disebut Undang-Undang Pokok Agraria mengisyaratkan bahwa tanah itu pada tingkatan tertinggi dikuasai oleh negara sebagai organisasi seluruh rakyat. Dalam ketentuan dasar Undang-Undang Pokok Agraria (untuk selanjutnya disebut UUPA) dapat diketahui bahwa kesejahteraan dan kemakmuran rakyat yang menjadi prioritas tujuan utama dalam pemanfaatan fungsi bumi, air, dan ruang angkasa serta kekayaan alam yang terkandung di dalamnya. Misi untuk terlaksananya cita-cita bangsa Indonesia tersebut tercantum dalam UUPA khususnya di bidang pertanahan.

Sehubungan dengan itu UUPA memerintahkan diselenggarakannya pendaftaran tanah dalam rangka menjamin kepastian hukum. ${ }^{1}$ UUPA telah mengatur adanya keharusan untuk melaksanakan pendaftaran tanah sebagai jaminan kepastian hak dan kepastian hukum atas tanah di seluruh Indonesia, sebagaimana disebut dalam Pasal 19 UUPA. Pasal tersebut mencantumkan ketentuan-ketentuan umum dari pendaftaran tanah di Indonesia, yaitu :2

1. Untuk menjamin kepastian hukum oleh pemerintah diadakan pendaftaran tanah di seluruh wilayah Republik Indonesia menurut ketentuanketentuan yang diatur dengan Peraturan Pemerintah.

2. Pendaftaran tersebut dalam ayat 1 Pasal ini meliputi: Pengukuran, perpetaan dan pembukuan tanah.

a. Pendaftaran hak-hak atas tanah dan peralihan hak-hak tersebut.

b. Pemberian surat-surat tanda bukti hak, yang berlaku sebagai alat pembuktian yang kuat.

3. Pendaftaran tanah diselenggarakan dengan mengingat keadaan negara dan masyarakat, keperluan lalu lintas sosial ekonomi serta kemungkinan penyelenggaraannya, menurut pertimbangan Menteri Agraria.

4. Dalam peraturan pemerintah diatur biaya-biaya yang bersangkutan dengan pendaftaran termaksud dalam ayat (2) di atas, dengan ketentuan bahwa rakyat yang tidak mampu dibebaskan dari pembayaran biaya-biaya tersebut.

Ketentuan dalam Pasal 19 ayat (1) UUPA tersebut merupakan ketentuan yang ditujukan kepada pemerintah untuk menyelenggarakan pendaftaran tanah di seluruh wilayah Republik Indonesia, yang sekaligus merupakan dasar hukum bagi pelaksanaan pendaftaran tanah dalam rangka memperoleh surat tanda bukti

1 Boedi Harsono, Hukum Agraria Indonesia Sejarah PembentukanUndang-Undang Pokok Agraria, isi Dan Pelaksaannya, Jilid 1, Djambatan, Jakarta, 2002, hlm. 470.

2 Urip Santosa, Hukum Agraria Kajian Komprehensif, Kencana Prenada Media, Jakarta, 2012, hlm. 278. 
hak atas tanah yang berlaku sebagai alat pembuktian yang kuat. Sebagaimana dijelaskan dalam Pasal 23 ayat (1) UUPA tentang hak milik, demikian halnya dengan setiap peralihan dan hapusnya pembebanannya dengan hak-hak lain harus didaftarkan menurut ketentuan-ketentuan yang dimaksud dalam Pasal 19, dan Pasal 32 ayat (1) UUPA, tentang "Hak Guna Usaha", termasuk syarat-syarat pemberiannya, bahwa setiap peralihan dan penghapusan hak tersebut, harus didaftarkan menurut ketentuan-ketentuan sebagaimana yang dimaksud dalam Pasal 19 tersebut di atas. ${ }^{3}$

Menindaklanjuti ketentuan tersebut, telah dikeluarkan Peraturan Pemerintah Nomor 24 Tahun 1997 tentang Pendaftaran Tanah, sebagaimana penyempurnaan dari Peraturan Pemerintah sebelumnya yaitu Peraturan Pemerintah Nomor 10 Tahun 1961. Penyempurnaan Peraturan Pemerintah Nomor 24 Tahun 1997 ini tertuang dalam Pasal 1 yang jelas-jelas memberikan jaminan teknis dan jaminan hukum atas haknya. Sehingga pelaksanan pendaftaran tanah itu meliputi tugas teknis mulai dari pengukuran, letak tanah, batas bidang tanah, ketentuan fisik tanah serta keadaan bangunan yang ada di atas tanah tersebut dan tugas administrasi termasuk meneliti keabsahan bukti dan yang paling penting memelihara rekaman data pendaftaran dalam suatu daftar yang dapat dipertanggungjawabkan terhadap siapa saja. Penyelenggaraan pendaftaran tanah dalam masyarakat merupakan tugas administrasi negara yang diselenggarakan oleh Pemerintah bagi kepentingan rakyat dalam rangka memberikan kepastian hak atas tanah di Indonesia. ${ }^{4}$

Dibandingkan dengan Peraturan Pemerintah Nomor 10 Tahun 1961 yang terdiri dari 46 pasal maka Peraturan Pemerintah Nomor 24 Tahun 1997 yang terdiri 66 pasal ini lebih memperkaya ketentuan Pasal 19 UUPA, yaitu: ${ }^{5}$

a. Bahwa dengan diterbitkannya sertifikat hak atas tanah maka kepada pemiliknya diberikan kepastian hukum dan perlindungan hukum.

b. Di zaman informasi ini Kantor Pertanahan sebagai kantor dibaris depan haruslah terpelihara dengan baik setiap informasi yang diperlukan untuk sesuatu bidang tanah, baik untuk pemerintah sendiri sehingga dapat merencanakan pembangunan negara dan juga bagi masyarakat sendiri informasi itu penting untuk dapat memutuskan sesuatu yang diperlukan dimana terlibat tanah, yaitu data fisik dan yuridisnya ternasuk untuk satuan rumah susun informasi itu bersifat terbuka untuk umum artinya dapat diberikan informasi apa saja yang diperlukan atas sebidang tanah atau bangunan yang ada.

\footnotetext{
${ }^{3}$ Ibid., hlm. 279.

4 Mhd. Yamin Lubis dan Abd. Rahim Lubis, Hukum Pendaftaran Tanah, Edisi Revisi, Mandar Maju, Bandung, 2010, hlm. 107.

5 A.P. Parlindungan, Pendaftaran Tanah Di Indonesia Berdasarkan PP No 24 Tabun 1997 Dan Peraturan Jabatan PPAT, Mandar Maju, Bandung, 1999, hlm. 2.
} 
c. Sehingga untuk itu perlulah tertib administrasi pertanahan dijadikan suatu hal yang wajar.

Sebagaimana diuraikan di atas bahwa fungsi tanah sangat penting bagi kehidupan masyarakat. Namun dengan meningkatnya pembangunan dan bertambahnya jumlah penduduk, permasalahannya dan sengketa di bidang pertanahan semakin bertambah sekalipun peraturan sudah semakin sempurna. Di tambah lagi dengan kenyataan sekarang ini bahwa tanah yang sudah dipunyai seseorang tetapi sebagian besar belum terdaftar dan belum mempunyai alat bukti berupa sertipikat. Padahal pendaftaran tanah tersebut adalah sangat penting, dimana fungsi dari pendaftaran tanah tersebut adalah: 6

a. Mereka mempunyai tanah dengan mudah akan dapat membuktikan haknya atas tanah yang dikuasaidan dipunyainya. Kepada mereka masingmasing diberikan surat tanda bukti hak oleh pemerintah.

b. Mereka yang memerlukan keterangan yang dimaksudkan diatas, yaitu calon pembeli dan calon kreditur yang akan menerima tanah sebagai jaminan akan dengan mudah memperoleh, karena keterangan tersebut yang disimpan di Kantor Penyelenggaraan pendaftaran tanah, terbuka bagi umum dalam arti untuk boleh mengetahui dengan melihat sendiri daftar dan dokumen yang bersangkutan atau meminta keterangan tertulis mengenai data yang di perlukan dari kantor tersebut.

Terdapat kasus sengketa tanah di Kulon Progo dengan diterbitkannya Sertipikat Hak Milik Nomor 2092 atas nama Ranu Dikromo oleh Kantor Pertanahan Kabupaten Kulon Progo yang menempati Persil 62a P Kelas III milik Sonto Permono. Berdasarkan uraian tersebut di atas, maka penulis tertarik untuk meneliti dengan judul penelitian, "Mekanisme Penerbitan Sertipikat Hak Milik Oleh Kantor Pertanahan Yang Berdasarkan Pada Turunan Letter C"

\section{Rumusan Masalah}

Berdasarkan latar belakang permasalahan yang diuraikan di atas, penulis dapat merumuskan permasalahan yaitu bagaimana mekanisme penerbitan dan kepastian hukum Sertipikat Hak Milik Nomor 2092/Margosari atas nama Ranu Dikromo yang menempati Persil 62a P Kelas III atas nama Sonto Permono?

\footnotetext{
${ }^{6}$ Ibid., hlm. 153.
} 


\section{Tujuan Penelitian}

Untuk mengetahui mekanisme penerbitan dan kepastian hukum Sertipikat Hak Milik Nomor 2092/Margosari atas nama Ranu Dikromo yang menempati Persil 62a P Kelas III atas nama Sonto Permono bagaimana keabsyahannya.

\section{Metode Penelitian}

\section{Jenis dan Sifat Penelitian}

Berdasarkan rumusan masalah dan tujuan penelitian maka jenis penelitian yang digunakan adalah penelitian yuridis empiris. Penelitian yuridis empiris merupakan penelitian dengan meneliti data sekunder terlebih dahulu untuk kemudian dilanjutkan dengan mengadakan penelitian terhadap data primer di lapangan.

Segi yuridis dalam penelitian ini ditinjau dari sudut hukum dan peraturanperaturan yang tertulis sebagai data sekunder, sedangkan yang dimaksud dengan pendekatan secara empiris tentang hubungan dan pengaruh hukum terhadap masyarakat dengan jalan melakukan penelitian atau terjun langsung ke dalam masyarakat atau lapangan untuk mengumpulkan data obyektif, data ini merupakan data primer. ${ }^{7}$ Untuk penelitian ini dititik beratkan pada langkah-langkah pengamatan dan analisa yang bersifat empiris, yang akan dilakukan di lokasi penelitian.

\section{Obyek Penelitian}

Mekanisme penerbitan dan kepastian hukum Sertipikat Hak Milik Nomor 2092 Desa Margosari oleh Kantor Pertanahan Kulon Progo yang didasarkan pada Letter C No. 43/I Persil 62a P Kelas III, yang Letter C tersebut mempunyai kekuatan hukum tetap berdasarkan putusan Mahkamah Agung Nomor Reg. No. 3289 K/Pdt/1993 yang memperkuat putusan Pengadilan No. 11/Pdt/G/1992/PN.Wt.

\section{Sumber Data}

\section{a. Data Primer}

Sumber Data Primer atau data dasar (primary data atau basic data) adalah data yang diperoleh langsung dari sumber pertama. ${ }^{8}$ Dalam hal ini adalah pihak-pihak yang yang berhubungan langsung dengan penelitian ini, baik wawancara dengan ahli waris almarhum Bapak Sonto Permono, Ibu Rubinem dan Sekdes Margosari.

\footnotetext{
${ }^{7}$ P. Joko Subagyo, Metode Penelitian Dalam Teori Dan Praktek, Rineka Cipta, Jakarta, 1991, hlm. 91.

${ }^{8}$ Soerjono Soekanto, Pengantar... Op. Cit., hlm. 12.
} 


\section{b. Data Sekunder}

Data sekunder ini terdiri dari bahan-bahan hukum, yaitu :

1) Bahan hukum primer, yaitu bahan-bahan hukum yang mempunyai kekuatan hukum yang mengikat berupa peraturan perundang-undangan yang mengatur tentang sertipikat hak atas tanah.

2) Bahan hukum sekunder, yaitu bahan-bahan yang erat kaitannya dengan bahan hukum primer dan dapat membantu menganalisis dan memahami bahan hukum primer, yaitu buku-buku literatur hukum dan artikel-artikel serta tulisan-tulisan yang berkaitan dengan permasalahan yang akan diteliti.

\section{Metode Pengambilan Sampel}

Metode pengambilan sampel penelitian ini menggunakan teknik snowball sampling atau dilakukan secara berantai dengan meminta informasi kepada orang yang telah diwawancarai atau dihubungi sebelumnya, demikian seterusnya. ${ }^{9}$

Pada langkah awal jumlah subyek yang akan dijadikan sumber data dalam penelitian ini berjumlah 3 orang, yaitu Sucipto Widarso (ahli waris Bapak Sonto Permono), Rubinem (ahli waris Ranu Dikromo dan pemegang SHM No. 2092/Margosari) dan Sekdes Desa Margosari serta pejabat dari Kantor Pertanahan Kabupaten Kulon Progo. Dalam pelaksanaan penelitian, peneliti tidak akan membatasi jumlah subyek penelitian maupun karakteristik sampel, sesuai dengan pemahaman konseptual yang berkembang di lapangan. Pengambilan data akan dihentikan apabila peneliti telah merasa data yang terkumpul telah cukup akurat. Hal ini sesuai dengan konsep titik saturasi (saturation point) ketika penambahan data tidak lagi memberikan tambahan informasi baru dalam analisis. ${ }^{10}$

\section{Teknik Pengumpulan Data}

Teknik pengumpulan data yang akan digunakan oleh penulis adalah sebagai berikut :

a. Cara pengumpulan data yang primer dilakukan dengan wawancara, yaitu dengan tipe wawancara terarah yaitu dengan cara menyampaikan pertanyaanpertanyaan kepada yang diwawancarai untuk dapat menjawab, menggali jawaban lebih dalam, dan mencatat jawaban dari yang diwawancarai.

${ }^{9}$ Poerwandari E. Kristi, Metodologi Penelitian Sosial, Universitas Terbuka, Jakarta, 1998, hlm. 12.

${ }^{10}$ Poerwandari E. Kristi, Metode..., Op. Cit., hlm. 13. 
b. Cara pengumpulan data yang bersifat sekunder dengan cara mengidentifikasi, mempelajari peraturan perundang-undangan yang berlaku, serta buku-buku, dan tulisan-tulisan yang berkaitan dengan penelitian.

\section{Hasil Penelitian dan Pembahasan}

\section{Mekanisme Penerbitan Sertipikat Hak Milik Nomor 2092/ Margosari oleh Kantor Pertanahan Kabupaten Kulonprogo yang Didasarkan pada Turunan Letter C}

Kegiatan pensertipikatan tanah dengan Prona dimulai dengan pembuatan peta dasar pendaftaran yang diatur secara lengkap dalam Peraturan Menteri Negara Agraria Nomor 3 Tahun 1997 tentang Ketentuan Pelaksanaan Peraturan Pemerintah Nomor 24 Tahun 1997 tentang Pendaftaran Tanah. ${ }^{11}$

Persyaratan yang menjadi kewajiban peserta Prona yang alas hak adalah turunan Letter $C$ atau sejenisnya, berdasarkan wawancara dengan Sekdes Desa Margosari adalah: ${ }^{12}$

1. Foto copy Kartu Tanda Penduduk (KTP) dan Kartu Keluarga (KK) pemohon;

2. Asli petok D, Letter C atau foto copy Letter C/Kutipan C Desa;

3. Melampirkan bukti-bukti asli kepemilikan/ perolehan tanah antara lain: Akta Jual Beli/ Hibah/ Tukar Menukar/ Surat Keterangan Waris/ Segel/ Kuitansi / Surat Pernyataan di Bawah Tangan;

4. Melampirkan riwayat tanah yang dibuat oleh Kepala Desa/Lurah;

5. Melampirkan SPPT PBB tahun berjalan dan bukti pembayarannya;

6. Melampirkan permohonan penerbitan sertipikat;

7. Surat pernyataan penguasaan fisik bidang tanah;

8. Surat pernyataan tanah tidak dalam sengketa;

9. Surat pernyataan tanah tidak dalam jaminan;

10. Menunjukkan letak dan batas-batas tanah yang dimohon;

11. Memasang tanda batas bidang tanah yang dimohon;

12. Menyerahkan bukti setor BPHTB dan PPh;

Tahapan-tahapan Penerbitan Sertipikat

a. Pengumpulan Data Fisik

b. Pengumpulan dan Penelitian Data Yuridis

c. Pengumuman Data Fisik dan Data Yuridis

d. Penegasan Konversi dan Penerbitan SK Pengakuan Hak Tanah

e. Pembukuan Hak

f. Penerbitan Sertipikat

${ }^{11}$ Lihat Pasal 12, Pasal 13, Pasal 14, Pasal 15, Pasal 16, Pasal 17 dan Pasal 18 Peraturan Menteri Negara Agraria/Kepala Badan Pertanahan Nasional Nomor 3 Tahun 1997.

12 Wawancara dengan Sekretaris Desa Margosari, di Margosari, Pengasih, Kulon Progo, pada 7 Januari 2020 . 
Menurut hasil penelitian di lapangan mekanisme penerbitan Sertipikat Hak Milik Nomor 2092/Margosari atas nama Ranu Dikromo yang dikeluarkan oleh Kantor Pertanahan Kabupaten Kulon Progo sudah memenuhi syarat formil dan melalui tahapan-tahapan yang ditentukan oleh Peraturan Pemerintah No. 24 Tahun 1997 tentang Pendaftaran tanah dan Peraturan Menteri Negara Agraria/Kepala Badan Pertanahan Nasional Nomor 3 Tahun 1997 tentang Ketentuan Pelaksanaan Peraturan Pemerintah Nomor 24 Tahun 1997 tentang Pendaftaran Tanah.

Menurut Kantor Pertanahan Kabupaten Kulonprogo setelah melihat foto copy Sertipikat Hak Milik Nomor 2092/Margosari menyimpulkan mengenai data fisik dan data yuridis sudah sesuai yang dimuat dalam surat ukur sertipikat jadi sertipikat ini tidak ada permasalahan, karena sudah memenuhi syarat formil penerbitan sertipikat hak atas tanah dalam permohonan pendaftaran tanah apabila ada manipulasi atau yang tidak benar dalam persyaratan permohonan pendaftaran menjadi resiko pemohon sendiri.

Menurut penelitian terdapat unsur perbuatan melawan hukum yang dilakukan oleh pihak Ranu Dikromo yaitu memanipulasi data yuridis dan data fisik. Obyek pendaftaran yaitu bidang-bidang tanah Turunan Letter C No. 43/I atas nama Ranu Dikromo sebagian dari Persil No. 62a P Kelas III, akan tetapi ikut memasukkan bidang tanah milik Sonto Permono seluas $705 \mathrm{~m}^{2}$ yang merupakan bagian dari Persil 62a P Kelas III dari Turunan Letter C Nomor 46/I atas nama Sonto Permono.

Apabila mencermati Putusan Pengadilan Negeri Wates Nomor 11/Pdt/G/1992/PN.Wt. dan diperkuat dengan Putusan Mahkamah Agung Reg. No. $3289 \mathrm{~K} / \mathrm{Pdt} / 1993$ dalam kasus sengketa antara Ranu Dikromo sebagai Penggugat dan Tergugat I Parto Ikromo dan Tergugat II Bupati Kepala Daerah Dati II Kulon Progo bahwa tanah Ranu Dikromo yang berada di selatan jalan yang merupakan obyek pendaftaran tanah hanya seluas $510 \mathrm{~m}^{2}$ dikurangi kepotong proyek jalan Desa pada tahun 1980, dan berada disebelah barat bidang tanah Persil 62a P Kelas III milik Sonto Permono. Hasil pendaftaran hak atas tanah dan terbit SHM No. 2092/Margosari atas nama Ranu Dikromo terdaftar dalam Surat Ukur tanggal 1-4-1998 No. 1646/98 dengan luas 1160m².

Dalam membuat Surat Penguasaan fisik atas bidang tanah sebagai salah satu syarat permohonan pendaftaran ada kemungkinan dimanupulasi karena bertentangan dengan kenyataan, karena yang secara nyata menguasai tanah tersebut adalah pihak Sonto Permono. Tanah pekarangan tersebut dimiliki dan dikuasai oleh ahli waris Sonto Permono dari dulu sampai sekarang belum pernah 
beralih. Tanah tersebut merupakan sebagian dari Persil 62a Kelas P III yang luasnya $2965 \mathrm{~m}^{2}$ yang dibeli dari Suro Gati dan disaksikan Suro Mijo dan Pringgo Wiyono pada 1959 tercatat dalam letter C. Dalam bukti kepemilikan Model E No. 28 yang dikeluarkan Dinas Agraria Pemerintah Daerah Istimewa Yogyakarta atas nama Sonto Permono dan Turunan Letter C Desa Margosari Nomor 46/I terdiri dari Persil 63c P Kelas IV seluas 3850m², Persil 62a P Kelas III seluas 230m² dan Persil 62a Kelas P III seluas 2965m².

Terdapat juga unsur kelalaian dari Panitia Prona, Satgas Pengumpulan data fisik dan data yuridis karena kurang teliti dalam penetapan batas, dan pengukuran saat pengumpulan data fisik karena hanya mengikuti kemauan pemohon yang dimungkinkan bekerjasama dengan oknum anggota Panitia Prona dari perangkat desa (oknum mantan kepala Dukuh). Pada saat penetapan batas, pemasangan batas dan pengukuran Satgas pengukuran dan pemetaan seharusnya menurut ketentuan Pasal 19 ayat (1) huruf b Permen Agraria/Kepala BPN No. 3/1997 yaitu dengan kesepakatan pemegang hak atas bidang tanah yang berbatasan. Pada saat pengukuran pihak Sonto Permono tidak hadir karena tidak di undang atau mungkin surat undangan tidak disampaikan, karena tanah tersebut sudah terpasang tanda batas sebagai calon pembagian harta warisan untuk anak-anak ahli waris Sonto Permono kelak dan dipasang saat Sonto Permono masih hidup, saksi pemasang tanda batas masih hidup sampai sekarang yaitu Suwarno dan Edi Untoro yang merupakan tetangganya. ${ }^{13}$

Panitia A kurang teliti dalam memeriksa dan meneliti alat-alat bukti tertulis kepemilikan hak atas tanah, seharusnya apabila mencurigakan karena Ranu Dikromo pernah bersengketa dengan Parto Ikromo dalam sengketa di Pengadilan Wates dengan Nomor 11/Pdt/G/1992/PN.Wt. penelitian perlu ditambah bukti dengan sekurang-kurangnya keterangan 2 saksi yang dapat dipercaya warga setempat yang tidak mempunyai hubungan keluarga yang bersangkutan sampai derajad kedua dalam kekerabatan baik vertikal maupun horizontal, sehingga benarbenar dapat disimpulkan bahwa dirinya secara nyata memiliki/menguasai tanah tersebut atau tidak. Dengan surat pernyataan dan ditambah 2 saksi akan menambah kuat bukti bagi Panitia dalam meneliti dan mengumpulkan data yuridis.

\section{Kepastian Hukum Sertipikat Hak Milik Nomor 2092/ Margosari atas Nama Ranu Dikromo yang Menempati Persil 62a P Kelas III atas Nama Sonto Permono}

Hasil penelitian langsung dilapangan yang menemukan fakta-fakta dalam penerbitan Sertipikat Hak Milik No. 2092/Margosari atas nama Ranu Dikromo

13 Wawancara dengan Bapak Sucipto Widarso, di Margosari, Pengasih, Kulon Progo, pada tanggal 2 Desember 2019. 
alas hak berasal dari Turunan Letter C No. 43/I Persil 62a P Kelas III dan dikonferhensi dengan Peraturan Perundang-undangan terkait pendaftaran tanah yang berlaku di Indonesia, akan disajikan sebagai berikut:

Sistem Publikasi yang digunakan di Indonesia adalah sistem negatif yang mengandung unsur positif. Pendaftaran tanah menurut PP 10/1961 junto PP 24/1997 akan menghasilkan surat-surat tanda bukti hak yang berlaku sebagai alat pembuktian yang kuat, seperti dinyatakan dalam Pasal 19 ayat (2) huruf c, Pasal 23 ayat (2), Pasal 32 ayat (2) dan Pasal 36 ayat (2) UUPA, bukan sistem publikasi negatif yang murni. Sistem publikasi negatif murni tidak akan menggunakan sistem pendaftaran hak. Sebagaimana kita lihat pada ketentuan-ketentuan yang mengatur prosedur-prosedur pengumpulan sampai penyajian data fisik dan data yuridis yang diperlukan serta pemeliharaannya dan penerbitan sertipikat haknya, biarpun sistem publikasinya negatif, tetapi kegiatan-kegiatan dilaksanakan secara seksama, agar data-data yang disajikan sejauh mungkin dapat dipertanggung jawabkan kebenarannya. ${ }^{14}$

Sifat pembuktian sertipikat tanah sebagai tanda bukti hak disebutkan dalam Pasal 19 ayat (2) huruf c UUPA, yaitu sertipikat berlaku sebagai alat pembuktian yang kuat, yaitu data fisik dan data yuridis yang dimuat dalam sertipikat dianggap benar sepanjang tidak dibuktikan sebaliknya oleh alat bukti lain yang dapat berupa sertipikat atau selain sertipikat. Berdasarkan sifat pembuktian ini, pihak yang merasa dirugikan atas diterbitkannya sertipikat dapat mengajukan gugatan ke pengadilan untuk mengajukan permohonan agar sertipikat yang diterbitkan tersebut tidak sah. Kalau putusan pengadilan sudah mempunyai kekuatan hukum tetap yang menyatakan bahwa sertipikat tersebut tidak sah, maka Kepala Badan Pertanahan Nasional Republik Indonesia menerbitkan surat keputusan tentang pembatalan sertipikat. ${ }^{15}$

Kepastian hukum dan perlindungan hukum kepada pemegang hak atas nama yang tercantum dalam sertipikat sebagai alat pembuktian yang mutlak yang diberikan Pasal 32 ayat (2) Peraturan Pemerintah Nomor 24 Tahun 1997 tentang Pendaftaran Tanah atas SHM No. 2092/Margosari yang terbit atas nama Ranu Dikromo pada 1998 yang berdasarkan turunan Letter C No. 43/1 Persil 62a P Kelas III masih mungkin untuk dibatalkan keabsahannya, karena menempati di bidang tanah Persil 62a P Kelas III milik Sonto Permono sehingga merugikan pihak pemilik atas bidang tanah yang sebenarnya.

14 Boedi Harsono, Hukum..., Op. Cit., hlm. 477-478.

15 Urip Santosa, Hukum... Op. Cit., hlm. 317-318. 
Ketentuan Pasal 32 ayat (1) Peraturan Pemerintah Nomor 24 Tahun 1997 tentang Pendaftaran Tanah menjelaskan bahwa : "Sertipikat merupakan surat tanda bukti hak yang berlaku sebagai alat pembuktian yang kuat mengenai data fisik dan data yuridis yang termuat didalamnya, sepanjang data fisik dan data yuridis tersebut sesuai dengan data yang ada dalam surat ukur dan buku tanah yang bersangkutan."

Ketentuan Pasal 32 ayat (1) tersebut masih ada celah dan mempunyai kelemahan yaitu negara tidak menjamin data fisik dan data yuridis yang disajikan dan tidak adanya jaminan bagi pemilik sertipikat, dikarenakan sewaktu-waktu akan mendapatkan gugatan dari pihak lain yang merasa dirugikan atas diterbitkannya sertipikat tersebut. Untuk menutupi kelemahan dalam ketentuan Pasal 32 ayat (1) tersebut, maka dalam Pasal 32 ayat (2) memberikan perlindungan hukum kepada pemilik sertipikat dari pihak lain dan menjadikannya sertipikat sebagai tanda bukti yang bersifat mutlak, ayat (2) yang berbunyi:

"Dalam hal atas suatu bidang tanah sudah diterbitkan sertipikat secara sah atas nama orang atau badan hukum yang memperoleh tanah tersebut dengan itikad baik dan secara nyata menguasainya, maka pihak lain yang merasa mempunyai hak atas tanah itu tidak lagi dapat menuntut pelaksanaan hak tersebut apabila dalam lima (5) tahun sejak diterbitkannya sertipikat itu tidak mengajukan keberatan secara tertulis kepada pemegang sertipikat dan Kepala Kantor Pertanahan yang bersangkutan ataupun tidak mengajukan gugatan ke Pengadilan mengenai penguasaan tanah atau penerbitan sertipikat tersebut."

Konsekuensi dari ketentuan Pasal 32 ayat (2) ini, Sertipikat sebagai tanda bukti hak yang bersifat mutlak apabila memenuhi unsur-unsur secara kumulatif yaitu :

1) Sertipikat diterbitkan secara sah atas nama orang atau badan hukum;

2) Tanah diperoleh dengan itikad baik;

3) Tanah dikuasai secara nyata;

4) Dalam waktu 5 tahun sejak diterbitkannya sertifikat itu tidak ada yang mengajukan keberatan secara tertulis kepada pemegang sertipikat dan Kepala Kantor Pertanahan Kabupaten/Kota setempat ataupun tidak mengajukan gugatan ke pengadilan mengenai penguasaan tanah ataupun penerbitan sertipikat.

Ketentuan yang menyatakan pihak lain yang merasa mempunyai hak atas tanah itu tidak lagi dapat menuntut pelaksanaan hak tersebut apabila dalam 5 tahun sejak diterbitkannya sertipikat itu tidak mengajukan keberatan secara tertulis kepada pemegang sertipikat dan Kepala Kantor Pertanahan yang bersangkutan ataupun tidak mengajukan gugatan ke Pengadilan mengenai 
penguasaan tanah atau penerbitan sertipikat merupakan kepastian hukum dan perlindungan hukum terhadap pemegang sertipikat, syarat dari ketentuan ini yaitu : "Sertipikat diterbitkan secara sah atas nama badan hukum atau orang; tanah diperoleh dengan itikad baik memperolehnya dan tanah dikuasai secara nyata."

Tanpa terpenuhi empat unsur tersebut secara kumulatif, maka sertipikat sebagai surat tanda bukti hak tidak berlaku sebagai alat pembuktian yang mutlak yang diberikan Pasal 32 ayat (2) PP 24/1997 artinya masih bisa diganggu gugat pihak lain yang bisa membuktikan sebagai pemilik yang sebenarnya di Pengadilan.

a. Unsur-unsur yang Menghapus Ketentuan Pasal 32 ayat (2) PP 24/1997 di SHM No. 2092/Margosari Sebagai Alat Pembuktian yang Mutlak

1) Salah satu syarat permohonan pendaftaran tanah adalah foto copy Letter $C$

Turunan Letter C yang di ajukan oleh Ranu Dikromo adalah Letter C Desa Margosari Nomor 43/I, Persil No. 62a P Kelas III dengan luas $4.150 \mathrm{~m}^{2}$. Menurut fakta-fakta bahwa Letter C Desa Margosari Nomor 43/I, Persil No. 62a P Kelas III pernah terdaftar jadi obyek pokok perkara di Kepaniteraan Pengadilan Negeri Wates No. 11/Pdt/G/1992/PN.Wt. berdasarkan Putusan Mahkamah Agung Reg. No. 3289 K/Pdt/1993. yang memperkuat putusan No. 11/Pdt/G/1992/PN.Wt. tersebut, bisa disimpulkan bahwa Ranu Dikromo hanya memiliki tanah seluas $510 \mathrm{~m}^{2}$ yang berada di selatan jalan dan merupakan bagian dari total luas $3.475 \mathrm{~m}^{2}$ dalam Letter C N0. 43/I Persil 62a P Kelas III, akan tetapi yang didaftarkan sebagian dari $1.500 \mathrm{~m}^{2}$ dan juga mempunyai unsur itikad tidak baik.

\section{2) Tanah Diperoleh Dengan Itikad Tidak Baik}

Menurut pengamatan dan mencermati data-data dari penelitian, bisa dikatakan Ranu Dikromo tidak dengan itikad baik karena menyerobot tanah milik Sonto Permono seluas $705 \mathrm{~m}^{2}$ untuk didaftarkan menjadi hak miliknya. Berdasarkan keterangan Sucipto Widarso saat penetapan batas-batas tanah, pemasangan batas-batas tanah dan pengukuran secara sembunyi-sembunyi. Padahal menurut ketentuan Pasal 19 jo. Pasal 58 Permenag No. 3/1997 harus disaksikan oleh pemilik tanah dan pemegang atas bidang tanah yang berbatasan pada waktu yang telah ditentukan sebelumnya dan ada kesepakatan mengenai penetapan batas-batas tanah dan pemasangan batasbatas tanah. Cara tersebut tidak patut karena secara sembunyi-sembunyi dan tidak sah karena bertentangan dengan aturan yang berlaku. 
Secara spesifik tidak ada yang mengatur tentang itikad baik dalam pendaftaran tanah baik itu pada UUPA, PP No. 24/1997 dan Permenag No. 3/1997. Akan tetapi Dalam KUHPerdata, istilah itikad baik setidaknya disebutkan dalam Pasal 1341 ayat (2). Itikad baik disebut dalam konteks penghormatan atas hak-hak pihak ketiga yang diperoleh dengan itikad baik dari tindakan yang tidak sah.

Dari definisi di atas bisa ditarik kesimpulan Itikad baik adalah ada niat, maksud atau kemauan yang patut dan jujur tanpa maksud untuk menipu atau merugikan hak orang lain dan menguntungkan diri sendiri. Hak adalah kepentingan yang dilindungi hukum. ${ }^{16}$

Dari perolehan data dilapangan, disimpulkan saat penetapan batas-batas bidang tanah, pemasangan tanda batas-batas bidang tanah dan pengukuran atas bidang tanah untuk pengumpulan data fisik memperolehnya secara tidak patut, bertentangan dengan hukum dan dengan itikad tidak baik yang bertentangan Pasal 32 ayat (2) PP No. 24 Tahun 1997.

\section{3) Tanah dikuasai secara tidak nyata}

Dimungkinkan Ranu Dikromo memanipulasi surat pernyataan. Berdasarkan pengakuan sendiri dari hasil wawancara dengan Rubinem dirinya dari kecil tinggal di dekat lokasi tanah penelitian ini, sampai saat ini berusia 60 tahun belum pernah menggarap atau memanfaatkan tanah tersebut.

Menurut keterangan Sucipto Widarso tanah tersebut dari sejak dulu saat Sonto Permono masih hidup sampai sekarang dikuasai oleh pihaknya. Dan saat ini sebelah timur untuk tempat tinggal dirinya dan setengahnya di sebelah barat ditanami buah-buahan oleh adiknya yaitu Ngatinah, karena menurut petunjuk orang tuanya kelak diwariskan untuk Ngatinah.

Tanah pekarangan $705 \mathrm{~m}^{2}$ yang dimiliki dan dikuasai oleh ahli waris Sonto Permono merupakan sebagian dari Persil 62a Kelas P III yang luasnya $2965 m^{2}$ yang dibeli dari Suro Gati pada Tahun 1959. Dalam bukti kepemilikan Model E No. 28 yang dikeluarkan Dinas Agraria Pemerintah Daerah Istimewa Yogyakarta atas nama Sonto Permono, Turunan Letter C Desa Margosari Nomor 46/I terdiri dari Persil 63c P Kelas IV seluas 3950m², Persil 62a P Kelas III seluas 230m² dan Persil 62a Kelas P III seluas 2965m².

Bisa disimpulkan bahwa Sonto Permono adalah yang menguasai secara nyata, Ranu Dikromo tidak menguasai secara nyata terhadap tanah tersebut sebagai syarat sah untuk melakukan pendaftaran.

${ }^{16}$ Sudikno Mertokusumo, Mengenal Hukum Suatu Pengantar, Liberty, Yogyakarta, 2005, hlm. 43. 


\section{b. Langkah yang Bisa Ditempuh Ahli Waris Sonto Permono untuk Memperoleh Kembali Tanahnya Secara Sah}

Ada beberapa cara dalam menyelesaikan sengketa tanah dalam praktiknya, melalui Pengadilan Negeri (PN), melalui Pengadilan Tata Usaha Negara (PTUN) bahkan tidang jarang penyelesaian sengketa tanah merambah ke ranah wilayah hukum pidana karena dalam sengketa tersebut terkandung unsur-unsur pidana. Langkah diluar mekanisme peradilan juga bisa ditempuh, yaitu dengan cara mengajukan permohonan pembatalan sertipikat dapat dilakukan dengan pengajuan secara tertulis kepada Menteri atau Kementrian Agraria dan Tata Ruang/Badan Pertanahan Nasional melalui Kepala Kantor Pertanahan yang daerah kerjanya meliputi letak tanah yang bersangkutan.

Dari beberapa upaya hukum yang bisa ditempuh untuk memperoleh kembali atas sebagian bidang tanah Persil 62a P Kelas III seluas $702 \mathrm{~m}^{2}$ yang diserobot almarhum Ranu Dikromo, ahli waris Sonto Permono bisa mengajukan gugatan perbuatan melawan hukum ke Pengadilan Negeri Wates. Gugatan Ke Pengadilan Negeri Wates adalah upaya hukum yang paling tepat mengingat terbitnya SHM No. 2092/Margosari atas nama Ranu Dikromo adalah tahun 1998, dalam kasus ini terdapat unsur perbuatan melawan hukum yang menyerobot hak orang lain sehingga menyebabkan kerugian.

Perbuatan melawan hukum pengaturannya dalam Pasal 1365 Kitab Undang-Undang Hukum Perdata, menyatakan bahwa "Tiap perbuatan yang melanggar hukum dan membawa kerugian kepada orang lain, mewajibkan orang yang menimbulkan kerugian itu karena kesalahannya untuk menggantikan kerugian tersebut". Dari bunyi pasal tersebut, maka dapat disimpulkan unsur-unsur perbuatan melawan hukum adalah:

1) Ada perbuatan melawan hukum;

2) Ada kesalahan;

3) Ada hubungan sebab akibat antara kerugian dan perbuatan;

4) Ada kerugian.

Perbuatan melawan hukum berarti adanya perbuatan atau tindakan dari perilaku yang melanggar atau melawan hukum, baik itu hukum tertulis maupun hukum yang tidak tertulis. Unsur kesalahan di sini ada 2, bisa karena kesengajaan atau karena kealpaan. Kesengajaan maksudnya ada kesadaran yang oleh orang normal pasti tahu konsekuensi dari perbuatannya itu akan merugikan orang lain, sedangkan kealpaan berarti ada perbuatan mengabaikan sesuatu yang mestinya dilakukan, atau tidak berhati-hati atau teliti sehingga menimbulkan kerugian bagi orang lain. Namun demikian, adakalanya suatu keadaan tertentu dapat 
meniadakan unsur kesalahan, misalnya dalam hal keadaan memaksa (overmacht) atau si pelaku tidak sehat pikirannya (gila). ${ }^{17}$

Adanya Hubungan sebab akibat antara kerugian dan perbuatan (hubungan kasualitas) Maksudnya, ada hubungan sebab akibat antara perbuatan yang dilakukan dengan akibat yang muncul. Misalnya, kerugian yang terjadi disebabkan perbuatan si pelaku atau dengan kata lain, kerugian tidak akan terjadi jika pelaku tidak melakukan perbuatan melawan hukum tersebut. Dan akibat perbuatan pelaku menimbulkan kerugian, baik itu kerugian materil dan imateril. ${ }^{18}$

Dalam menentukan suatu perbuatan dapat dikualifikasi sebagai perbuatan melawan humum, diperlukan 4 syarat : ${ }^{19}$

1) Bertentangan dengan kewajiban hukum si pelaku;

2) Bertentangan dengan hak subyektif orang lain;

3) Bertentangan dengan kesusilaan ;

4) Bertentangan dengan kepatutan, ketelitian dan kehati-hatian.

Dalam kasus ini permohonan pendaftaran tanah yang dilakukan Ranu Dikromo memenuhi unsur perbuatan melawan hukum yang di tentukan oleh Pasal 1365 KUHPerdata, yaitu:

1) Ada perbuatan melawan hukum, yaitu persyaratan Letter C N0. 43/I Persil 62a P Kelas III milik Ranu Dikromo yang berada di selatan jalan hanya 510 m2 disebutkan secara jelas di dalam Putusan Mahkamah Agung Reg. No. 3289 K/Pdt/1993 yang memperkuat putusan No. 11/Pdt/G/1992 /PN.Wt. Perbuatan melawan hukum disini bahwa tanah yang milikinya hanya $510 \mathrm{~m}^{2}$ tetapi yang dijadikan obyek pendaftaran seluas $1.500 \mathrm{~m}^{2}$. Dimungkinkan ada manipulasi persyaratan, misalkan surat-surat pernyataan.

2) Ada kesalahan, yaitu kesalahan dan kelalaian petugas ukur dan pemetaan dalam penetapan batas dan pengukuran tanpa dihadiri dan kesepakatan pemegang hak tanah yang bersebelahan (pihak Sonto Permono).

3) Ada hubungan sebab akibat antara kerugian dan perbuatan, yaitu dengan di masukkannya sebagian Persil 62a P kelas III dari Letter C 46/I seluas $705 \mathrm{~m}^{2}$ milik Sonto Permono ke dalam obyek permohonan pendaftaran tanah oleh Ranu Dikromo mengakibatkan kerugian materi dan menghambat proses pendaftaran tanah yang akan dilakukan para ahli waris Sonto Premono.

4) Ada kerugian, yaitu ada kerugian material yaitu tanah yang bisa dinilai dengan uang seluas $705 \mathrm{~m}^{2}$ dan secara immaterial merugikan ahli waris hlm. 73 .

${ }^{17}$ Munir Fuady, Perbuatan Melawan Hukum: Pendekatan Kontemporer,PT. Citra Aditya Bakti, Bandung, 2002,

18 Ibid., hlm. 74.

${ }^{19}$ Rosa Agustina, Perbuatan Melawan Hukum, Pascasarjana FH UI, Jakarta, 2003, hlm. 117. 
Sonto Permono dikira orang banyak menguasai tanah miliknya Ranu Dikromo, padahal Pihak Sonto Permono lah pemilik yang sebenarnya.

Perbuatan melawan hukum berarti adanya perbuatan atau tindakan dari pelaku yang melanggar atau melawan hukum yang berlaku. Untuk menguatkan dalih-dalih bahwa terbitnya Sertipikat Hak Milik Nomor 2092/Margosari tidak sah secara hukum maka dibutuhkan alat bukti yang kuat dan bukti pendukung lainya. Dalam pembuktian suatu perkara perdata menurut ketentuan Pasal 1866 Kitap Undang-Undang Hukum Perdata telah mengatur jenis alat-alat bukti dalam hukum acara perdata, meliputi: bukti surat; bukti saksi; persangkaan; pengakuan; dan sumpah."

\section{a. Bukti-bukti surat pihak Sonto Permono}

1) Tanda Hak Milik Buku Model E No. 28, yang terdaftar Letter C No. 46/I yang terdiri Persil 63c P Kelas IV luas 3950 m², Persil 62a P Kelas III luas 230 dan Persil 62a P Kelas III atas nama Sonto Permono yang dikeluarkan Dinas Agraria Pemerintah Daerah Istimewa Yogyakarta yang disahkan dan diterbitkan pada 22 November 1971 adalah bukti otentik yang dikeluarkan pejabat yang berwenang. Menurut Peraturan Daerah Daerah Istimewa Yogyakarta No. 12 Tahun 1954 tentang Tanda Yang Sah Bagi Hak Milik Perseorangan Turun Temurun Atas Tanah (erferlijk individueel bezitsrecht) junto Peraturan Daerah Daerah Istimewa Yogyakarta No. 5 Tahun 1954 tentang Hak Atas Tanah Di Daerah Istimewa Yogyakarta junto Keputusan Kepala Daerah Daerah Istimewa Yogyakarta No. 209/1971 merupakan bukti sah sebagai bukti kepemilikan hak atas tanah di Daerah Istimewa Yogyakarta. ${ }^{20}$ Menurut Peraturan Daerah Istimewa Yogyakarta No. 12 Tahun 1954 jo. Peraturan Daerah No. 5 Tahun 1954 masalah tanah di Daerah Istimewa Yogyakarta mempunyai peraturan khusus atau tersendiri sebelum berlakunya UUPA secara resmi di DIY. Perda tersebut menentukan bahwa semua catatan mengenai tanah yang dibuat dihadapan pejabat Kelurahan adalah merupakan bukti otentik. ${ }^{21}$

2) Bukti putusan pengadilan yang mempunyai kekuatan hukum tetap yaitu Putusan Mahkamah Agung Reg. No. 3289 K/Pdt/1993 yang memperkuat putusan No. 11/Pdt/G/1992/PN.Wt. Putusan pengadilan yang sudah mempunyai kekuatan hukum tetap merupakan bukti otentik dalam pembuktian di Pengadilan. Dalam putusan di pengadilan tersebut menyebutkan bahwa tanah dalam Letter C 43/I Persil 62a P Kelas III atas nama Ranu Dikromo yang berada di selatan jalan (yang merupakan obyek pendaftaran tanah terbit menjadi SHM No. 2092/Margosari) adalah seluas

\footnotetext{
${ }^{20}$ Wawancara dengan Bapak Hersa Krisna Muslim, Notaris dan PPAT di Kulon Progo, di Lendah, Kulon Progo, pada tanggal 23 November 2020.

21 Putusan Mahkamah Agung Reg. No. 3289 K/Pdt/1993.
} 
510m² sebagian dari Letter C 43/I Persil 62a P Kelas III dari total luas keseluruhan $3.475 \mathrm{~m}^{2}$ yang merupakan pokok perkara gugatan di Pengadilan Wates No. 11/Pdt/G/1992/PN.Wts. Luasnya hanya $510 \mathrm{~m}^{2}$ dan menjadi obyek pendaftaran Ranu Dikromo menjadi SHM 2092/Margosari. Putusan pengadilan yang sudah mempunyai kekuatan hukum tetap tersebut juga bisa sebagai bukti otentik pembuktian di Pengadilan.

3) Bukti Surat Pembayaran Pajak Terutang (SPPT). SPPT NOP 34.010.070.004.002.0173.0 atas nama Sonto Permono seluas $1.850 \mathrm{~m}^{2}$ dan SPPT NOP 34.010.070.004.002.0167.0 atas nama Sonto Permono seluas $4.045 \mathrm{~m}^{2}$.

\section{b. Bukti saksi-saksi}

Saksi pemasangan Patok atau tanda batas-batas tanah, yaitu Suwarno dan Edi Untoro. Dan saksi saat pembelian tanah Sonto Permono dari Suro Gati yaitu bernama Suro Mijo dan Pringgo Wiyono yang masih hidup dan sanggup dijadikan saksi.

\section{c. Bukti pengakuan}

Pengakuan dari Rubinem belum pernah menguasai sama sekali bidang tanah tersebut.

Beradasarkan terpenuhinya unsur-unsur perbuatan melawan hukum tersebut, yang mengakibatkan tidak terpenuhinya ketentuan secara kumulatif sebagai syarat suatu Sertipikat hak atas tanah sebagai surat tanda bukti hak sebagai alat pembuktian yang mutlak atas kepemilikan tanah yang diberikan Pasal 32 ayat (2) PP 24/1997 karena sudah melewati 5 Tahun, maka ahli waris Sonto Permono masih ada upaya hukum untuk membatalkan SHM No. 2092/Margosari. Terbitnya sertipikat masih dapat digugat dan dibuktikan kebenarannya melalui Pengadilan. Upaya hukum yang dapat dilakukan oleh pihak almarhum Sonto Permono yaitu: mengajukan gugatan ke Pengadilan Negeri Wates mengenai perbuatan melawan hukum mengenai penerbitan sertipikat tersebut.

Ketentuan Pasal 32 ayat (2) Peraturan Pemerintah Nomor 24 Tahun 1997 tentang Pendaftaran Tanah masih bisa dianulir selama bisa dibuktikan bahwa perolehan tanah dilakukan tidak dengan iktikad baik dan secara nyata tidak menguasai tanah tersebut di Pengadilan. Majelis Hakim dengan adanya buktibukti yang kuat dan meyakinkan maka dapat dimintakan pembatalan SHM No. 2092/Margosari tersebut, akan tetapi apabila Majelis Hakim tidak membenarkan bukti-bukti tersebut maka Pengadilan akan menegaskan bahwa ahli waris almarhum Ranu Dikromo sebagai pemegang SHM No. 2092/Margosari adalah sah secara hukum sebagai pemilik atas bidang tanah tersebut.

Setelah sidang pembuktian di pengadilan selesai dan putusan pengadilan yang sudah mempunyai kekuatan hukum tetap, apabila pihak ahli waris Sonto 
Permono yang memenangkan gugatannya di pengadilan maka dengan putusan tersebut bisa digunakan sebagai permohonan perubahan Sertipikat Hak Milik Nomor 2092/Margosari dan juga permohonan pendfataran tanah lainnya yang tercantum di Letter No. 46/I Margosari. Apabila pengadilan menolak gugatan pihak Ahli waris Sonto Permono dan membenarkan penerbitan SHM No. 2092/Margosari maka pihak ahli waris Ranu Dikromo dengan mengacu putusan tersebut untuk meminta bidang tanah tersebut sebagai haknya, sehingga memiliki dan menguasai secara nyata dan memiliki bukti kepemilikan yaitu SHM No. 2092.

\section{Penutup}

Berdasarkan pembahasan yang telah dikemukakan penulis, maka pada akhir penulisan tesis ini penulis membuat suatu kesimpulan sebagai berikut. Pertama, mekanisme penerbitan Sertipikat Hak Milik Nomor 2092/Margosari atas nama Ranu Dikromo oleh Kantor Pertanahan Kabupaten Kulon Progo yang didasarkan dari letter $\mathrm{C}$ sudah memenuhi syarat formil dan melalui tahapantahapan yang ditentukan oleh PP. No. 24/1997 dan Permen No. 3/1997, akan tetapi terdapat unsur perbuatan melawan hukum yang dilakukan oleh pihak Ranu Dikromo yaitu memanipulasi persyaratan-persyaratan untuk mengajukan permohonan pendaftaran tanah.

Kedua, kepastian hukum terbitnya Sertipikat Hak Milik Nomor 2092/Margosari atas Ranu Dikromo masih dapat digugat dan dibuktikan kebenarannya melalui gugatan Pengadilan ke Pengadilan Negeri Wates. Berdasarkan bukti-bukti adanya perbuatan melawan hukum dari Ranu Dikromo, dan bukti-bukti kepemilikan atas tanah yang kuat yang dimiliki ahli waris Sonto Permono maka Sertipikat tersebut bisa dibatalkan dan dikembalikan ke pemilik yang sebenarnya. Ketentuan Pasal Pasal 32 ayat (2) Peraturan Pemerintah No. 24 Tahun 1997 tentang Pendaftaran Tanah bahwa sertipikat terbit melebihi masa 5 tahun tidak bisa diganggu gugat tidak berlaku karena tidak terpenuhinya syarat secara kumulatif yaitu sertipikat diterbitkan secara sah atas nama badan hukum atau orang; tanah diperoleh dengan itikad baik memperolehnya dan tanah dikuasai secara nyata.

\section{Daftar Pustaka}

Buku

Fuady, Munir. Perbuatan Melawan Hukum: Pendekatan Kontemporer, PT. Citra Aditya Bakti, Bandung, 2002. 
Harsono, Boedi. Hukum Agraria Indonesia Sejarah Pembentukan Undang-Undang Pokok Agraria, Isi Dan Pelaksanaannya, Jilid I. Djambatan, Jakarta, 2002.

Joko, P. Subagyo. Metode Penelitian Dalam Teori Dan Praktek, Rineka Cipta, Jakarta, 1991.

Kristi, Poerwandari E. Metodologi Penelitian Sosial, Universitas Terbuka, Jakarta, 1998.

Mertokusumo, Sudikno. Mengenal Hukum Suatu Pengantar, Liberty, Yogyakarta, 2005.

Parlindungan, A.P. Pendaftaran Tanah Di Indonesia Berdasarkan PP No. 24 Tahun 1997 dan Peraturan Jabatan PPAT, Mandar Maju, Bandung, 1999.

Santosa, Urip. Hukum Agraria Kajian Komprehensif, Kencana Prenada Media, Jakarta, 2012.

Soekanto, Soerjono. Pengantar Penelitian Hukum, Cetakan Ketiga, UI Press, Jakarta, 1986.

Sumarjono, Maria. Kebijakan Pertanahan Antara Regulasi Dan Implementasi, Kompas, Jakarta, 2001.

Yamin, Mhd. Lubis dan Abd. Rahim Lubis. Hukum Pendaftaran Tanah. Edisi Revisi. Mandar Maju, Bandung, 2010.

\section{Peraturan Perundang-undangan}

Kitap Undang-Undang Hukum Perdata.

Undang-Undang Nomor 5 Tahun 1960 tentang Peraturan Dasar Pokok-Pokok Agraria.

Undang-Undang Nomor 30 Tahun 2014 tentang Administrasi Pemerintahan

Peraturan Pemerintah Nomor 10 Tahun 1961 tentang Pendaftaran Tanah.

Peraturan Pemerintah Nomor 24 Tahun 1997 tentang Pendaftaran Tanah.

Peraturan Menteri Negara Agraria/Kepala Badan Pertanahan Nasional Nomor 3

Tahun 1997 tentang Ketentuan Pelaksanaan Peraturan Pemerintah Nomor

24 Tahun 1997 tentang Pendaftaran Tanah.

Peraturan Pemerintah Nomor 37 Tahun 1998 tentang Peraturan Jabatan Pejabat Pembuat Akta Tanah.

Peraturan Menteri Negara Agraria/Kepala Badan Pertanahan Nasional Nomor 9 Tahun 1999 tentang Tata Cara Pemberian dan Pembatalan Hak atas Tanah Negara dan Hak Pengelolaan.

Peraturan Daerah Darah Istimewa Yogyakarta No. 5 Tahun 1954 tentang Hak Atas Tanah Di Daerah Istimewa Yogyakarta.

Peraturan Daerah Daerah Istimewa Yogyakarta Nomor 12 Tahun 1954 tentang Tanda Yang Sah Bagi Hak Milik Perseorangan Turun Temurun Atas Tanah (erferlijk individueel bezitsrecht).

Putusan Mahkamah Agung Nomor Reg. No. 3289 K/Pdt/1993 yang mempekuat putusan Pengadilan No. 11/Pdt/G/1992/PN.Wt. 